\title{
The relevance of the Eemian for the study of the Palaeolithic occupation of Europe
}

\author{
Barbara Speleers ${ }^{1}$ \\ 1 Faculty of Archaeology, Leiden University, P.O. Box 9515, 2300 RA LEIDEN, \\ the Netherlands; e-mail: B.Speleers@arch.LeidenUniv.nl
}

Received: 20 February 1999; accepted in revised form: 15 February 2000

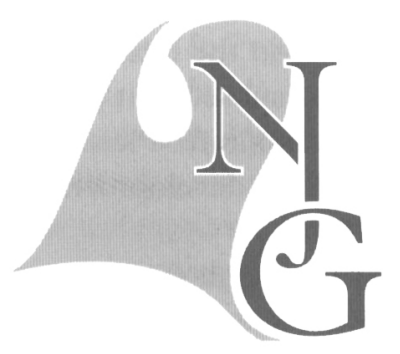

\begin{abstract}
The relevance of a study of the Eemian occupation of Europe lies largely in the discussion on the environmental tolerances of early humans and in the limits encountered during the reconstruction of Palaeolithic habitats. The traditional vision is reviewed; then follows a discussion of Gamble's studies $(1986,1987)$ in which he postulated an absence of human occupation in North-Western Europe during the Eemian. Gamble's explanatory models and the reactions to his work are presented. Finally, the relation is considered between the distribution pattern of sites, the former dispersal of early humans across the European landscape, and the implications of this evidence for hypotheses of environmental tolerances of Palaeolithic humans.
\end{abstract}

Kewords: archaeology, Middle Palaeolithic, taphonomy

\section{Introduction}

Interglacials were considered until quite recently as periods particularly well suited to occupation by Palaeolithic hunter-gatherers, who depended completely on their natural environment for their nutrition, both vegetable and animal. The warm-temperate climates of the interglacials supported rich deciduous forests in the mid-latitudes and high diversities of both small and larger animals. Tree and shrub species colonized northern Europe, with fruit-bearing trees appearing in the forests and allowing an extension of the vegetable diet of these foragers.

The interglacials frequently supported a greater diversity of animal species than the intervening glacials, particularly in herpetofauna but also in the mammal fauna. Large mammals were abundant in the Pleistocene interglacials, such as the straight-tusked elephant, rhinoceros, horse, bison, aurochs and deer, offering humans a wide choice of animals to hunt or scavenge.
A warm or temperate climate has traditionally been considered the optimal environment for human beings. High temperatures were supposed to give the humans the opportunity to live in the open, without temporary or permanent living structures. As pointed out by Obermaier (1912: 132): 'Als frei in der milden Natur herumschweifender fäger trat uns der Chelléenmensch [The Chelléen was, until the thirties, considered to be the oldest archaeological culture and was associated with a warm-temperate climate (De Mortillet, 1883); BS] entgegen, auch das strengere, von einem Steppenklima begleitete Acheuléen vermochte nur in seltenen Fällen dem damaligen Nomaden seine Liebe zur freien Natur zu vergällen, so daß er seine Jägerhalte noch allenthalben auf der offenen Prärie, am Waldsaum oder am Fuße schützender Felswände aufschlug. Erst das Moustérien zwang ihn ob seiner rauhen, eiszeitlichen Klimabedingungen, sich zu bleibendem Aufenthalt in geschlossene Höhlen oder unter gut gedeckte Felsschutzwände zu flüchten'.

The interglacials were described as almost utopian 
and - except for an occasional fight with wild animals - life was easy (De Mortillet, 1883; Obermaier, 1912). Glacial intervals were, by contrast, generally seen as harsh environments to live in; fire and clothing or a natural pelt were necessary to survive the low temperatures (Bordes \& Thibault, 1977). The snow cover would also have posed a significant problem, particularly in regard to foraging and hunting activities (Bordes \& Thibault, 1977). The cold climatic conditions were usually seen as the circumstances that initiated new adaptations from human beings in order to survive long periods of cold. Indeed, some archaeologists still hold that warmer climates lead to a cultural stillstand, and that life in the colder northern and middle latitudes forced early humans to cultural progress (Bosinski, 1992: 169).

\section{Early human climatological tolerance}

It is easy to understand the absence of early humans during the coldest parts of the glacial cycle, because of their limited adaptive capacities. Gamble (1986), however, suggested that humans failed to colonize Europe during the Eemian interglacial. His study of the behaviour of early and modern humans from an ecologic/economic perspective led him to notice a difference in terms of their climatological 'tolerance' in northern Europe.

In order to compare early and modern humans environmental tolerances, Gamble $(1986,1987)$ divided the interglacial/glacial cycle of the Middle and Late Pleistocene into three 'environmental' stages: (1) a full interglacial stage, (2) an intermediate climate stage, and (3) a glacial climate stage. Using the data from deep-sea core V28-238, he estimated the contribution of the various stages to the duration of the interglacial/glacial cycle, for the eight cycles of the Middle and the Late Pleistocene (spanning from 700-10 ka BP) (Gamble, 1987), as follows:

(1) Environmental stage 1:55.2 ka ( 8\%). This stage, which represents the interglacials, occupies only a small part of Middle and Late Pleistocene, and thus constitutes a somewhat exceptional phase in the climatic cycles of the Quaternary. One of the most pronounced of these interglacials is the Eemian (marine isotope stage [MIS] 5e). Human occupation was, according to Gamble, entirely absent during the Eemian in Great Britain, the Netherlands, Belgium, Germany, and northern France. When the archaeological evidence for settlement is considered, no occupation has been found in what was previously regarded as the optimum habitat for the Palaeolithic, i.e. the broadleaved forests of the last interglacial, and thus no colonization appeared after the glacials.

(2) Environmental stage 2: $386.4 \mathrm{ka}$ (56\%). This stage contains highly variable climates and environments, ranging from interstadials with boreal forests to cold steppes. The available archaeological evidence, as reviewed by Gamble, indicates that stage 2 environments were selectively favoured by humans before $35 \mathrm{ka} \mathrm{BP}$ (Gamble, 1987 ); in other words, before the appearance of modern humans in Europe.

(3) Environmental stage 3: $248.4 \mathrm{ka} \mathrm{(36 \% );} \mathrm{this} \mathrm{stage}$ shows little evidence for human occupation in northern Europe.

According to Gamble (1986), interglacial Europe was a more hostile environment for early humans than previously thought and this led him to propose various explanations. One explanation could be that, although interglacials represent intervals of high biomass productivity, the majority of the biomass is stored in nonedible form, like stems and leaves of trees. Moreover, the dispersion and small scale of the plant resources made them costly when measured by the time needed to collect them (Kelly, 1983). This contributed to exploitation costs that might have been too high for early humans and thus may have prevented colonization of the northern latitudes. The same is true for the animal food resources, although a large variety of species roamed the forests; they were scattered, in particular the 'rogue' species. Interglacial herd animals lived in smaller herds in comparison to the inhabitants of the 'mammoth steppe' (Guthrie, 1990).

To survive in such exceptional environments, humans required accurate and detailed information on the location of food resources. When the density of food resources is low, knowledge of their locations is necessary. Low densities make the resources vulnerable to (small-scale) climatic fluctuations. Information is the key to survival in areas where resources are varying with time. An important aspect of the tactics devised to cope with the spatial exploitation of resources refers to the structure and distribution of resource patches: whether they are clumped and widely separated in space or uniformly distributed (Heffley, 1981). Searching for food then becomes a group activity that requires cognitive and physical abilities to communicate and to plan ahead (Stringer \& Gamble, 1993; Whallon, 1989). In both warm and very cold environments, both characterized by the variable and dispersed nature of their resources, humans require the same planning skills to survive.

The absence of traces of occupation of north-western Europe during the Eemian led Gamble (1986) to conclude that Middle Palaeolithic people lacked the flexibility and skills to adapt to these environments 
and that modern humans were the first to survive under such exceptional environmental conditions. In Gamble's view, wooded environments were successfully exploited for the first time in the Holocene, though some researchers (Jacobi, pers. comm.) even argue that Mesolithic hunter-gatherers avoided the dense forests of the Holocene.

\section{Human occupation during the Eemian}

Roebroeks et al. (1992) refuted the basis of Gamble's model by concluding that a much wider range of environments was exploited by the Palaeolithic occupants of Northern Europe during the Pleistocene. They showed that archaeological sites are present from both glacials with cold open steppes and full interglacials with deciduous forests. The difference that Gamble (1986, 1987) had noticed between modern and archaic humans, in terms of their presence in certain climatic periods - which he interpreted in behavioural differences - was not confirmed by the observations of Roebroeks et al. (1992). They reported not only traces of occupation by archaic humans during climatic optima, but they also pointed to the fact that modern humans were not present during the last glacial maximum at northern latitudes (cf. Otte, 1990, Schmider, 1990; Noble \& Davidson, 1996). Hence they concluded that there was no significant difference in the presence between the two human species during the various climatic stages. As a consequence, early human planning abilities should, according to the models of Gamble $(1987,1995)$ and Whallon (1989), be considered far greater than thought thus far.

Artefactual evidence of human presence during the Eemian stems from Germany: flint artefacts have been found together with a yew spear at Lehringen (in Niedersachsen) and eight sites have been found in Sachsen. No evidence of human presence has, however, been found as yet in Great Britain, the Netherlands, western Belgium and northern France. The evidence of human occupation in the Eemian remains scarce in the Western part of Europe, and the presence of human occupation in 'exceptional' climates is still not acknowledged by some researchers as proof of the successful exploitation of 'extreme' environments by early humans (Gamble, 1992; Noble \& Davidson, 1996). Although the synchronic and diachronic evidence (Roebroeks et al., 1992) points to a potentially wide environmental tolerance for Middle Palaeolithic humans, Gamble (1995) suggests that present techniques and forms of environmental analysis reveal relatively little, because of the qualitative descriptions of past vegetation and landscapes. When there is no agreement on how accurate former environments can be reconstructed, the same data set can result in highly varying interpretations.

\section{The influence of taphonomy}

Gamble's study failed to take into account the full implications of modification of the settlement pattern by taphonomic processes, as proposed by Roebroeks et al. (1992) and by Wenban-Smith (1992: in a comment on Roebroeks et al.). Most studies rely heavily on the difference between absence and presence of archaeological sites and thus take implicitly the distribution pattern of sites as a correct reflection of the pattern of human occupation. Although the environmental settings of the sites are often described and the difference between glacial and interglacial settings are put forward, no analysis of the effects of differential preservation on the distribution pattern of sites is assessed in most studies. The modification of the pattern of sites through time by taphonomic processes can have a major influence on this distribution and thus before assessing behavioural models, it is important to analyse the complexity of the formation processes (Rigaud \& Simek, 1987).

The archaeological record is shaped by the same processes that influence the landscape (Butzer, 1982; Schiffer, 1987; Waters, 1992; Waters \& Kuehn, 1996). Local geomorphological conditions determine whether an archaeological site is preserved or destroyed soon after people have left. Because a long period may have passed since humans visited a particular site, the geomorphological conditions may have changed, for instance as a result of climatic changes. Each subsequent degradational event destroys more of the residual geological and archaeological record. The nature and completeness of the buried archaeological record thus parallels the nature and completeness of the geological sequence (Waters \& Kuehn, 1996).

\section{Taphonomy of the Eemian record}

The present contribution is intended to provide a framework in which models dealing with the behaviour of last-interglacial humans can be built by systematic analysis of the taphonomic processes that have influenced the distribution of the Eemian archaeological sites. The distribution of these sites depends primarily on landscape use by the Neanderthals. The archaeological sites, as they appear now, represent a very small part of the original number; the following three major factors are mainly responsible for this: 
(1) visibility: the recognition of Eemian Palaeolithic sites;

(2) the spatial distribution of Eemian sediments;

(3) accessibility: the possibility of recovering Eemian sediments.

\section{Visibility}

It is impossible on the basis of archaeological remains alone to determine whether a site is of Eemian age or not, because there are no artefacts typical of the Eemian; Middle Palaeolithic assemblages are in general quite uniform over the 250,000 years of the Middle Palaeolithic. As a consequence, archaeology relies heavily on other disciplines to assign archaeological assemblages to individual stages. The stratigraphical position is the first criterion to provide a relative age estimate of an archaeological site. For example, the sites found in lacustrine deposits in the Thuringia basin are all found above the tills of the Drenthe glaciation. All these lacustrine deposits are covered by Weichselian loesses or loess derivatives. In some of these lacustrine deposits, early Weichselian temperate- and cold-climate intervals have been found among others at Gröbern (see, for instance, Litt, 1994). Such evidence allows the artefact concentrations to be assigned a fairly accurate age. In Germany, some scientists hold that a warm stage existed between the two ice advances of the Saalian, but in the absence of clear stratigraphical evidence for a warm interval between the Drenthe and the Warthe glaciations, the present author follows Eissman (1994: 88) and Ehlers (1996: 281) in assigning all post-Drenthe interglacial sequences to the Eemian stage.

When the archaeological sites are situated beyond the maximum extent of the Saalian ice cap, assigning a stratigraphical position is often more difficult, and consequently other proxy data are required. For the Eemian, palynological evidence must be relied upon. Pollen or botanical macro-remains are the most important fossils in this context, but faunal evidence can also be used as a chronostratigraphical tool. A consequence of this reliance on biological remains for dating Eemian sites is that the only sequences recognised are those where the sedimentary situation was favourable for the preservation of organic remains. Thus archaeological sites that are associated with organic sediments or calcareous waterlain deposits are recognised, which implies a bias in favour of wet environments. This means that a range of landscape categories are not represented in the dataset, for instance all former dry environments. This does not mean that there are no archaeological traces in such localities; it rather means that they cannot be recognised in terms of belonging to a specific interglacial. All surface finds that lack stratigraphic or environmental context are impossible to date as Eemian artefacts. The consequence is that regions such as the Mittelgebirge in Germany and the wide loess plateaus of northern France might be under-represented in the dataset, because of the lack of organic deposits.

\section{Distribution of Eemian sediments}

The specific sedimentary settings in which archaeological evidence of Eemian occupation in northern Europe is preserved, are spatially restricted (Fig. 1). Artefacts have been recovered from former lacustrine environments at five localities. The artefacts were located in sandy lake shores, except at Lehringen, where flint artefacts were found within lake marls around a skeleton of a Palaeoloxodon antiquus, some $20 \mathrm{~m}$ from the contemporaneous shoreline (Thieme $\&$ Veil, 1985). The Neumark-Nord lake sequence includes two sandy layers that continue laterally some distance into the lacustrine sediments and both strata have yielded Palaeolithic artefacts (Mania et al., 1990). The shorelines of the lakes at Gröbern (Heussner \& Weber ,1990; Weber \& Litt, 1991) and Rabutz (Toepfer, 1958) were overlain by lacustrine sediments and the artefacts were found in single concentrations, which suggests that humans visited the locality only once. At Grabschütz, the artefacts were eroded (Weber, 1990) and must have been lying on the surface for a long time before they were buried during the Weichselian. The Eemian lakes occupied glacial depressions that originated from the Saalian glaciation, and had been formed during the retreat of the glaciers. Being related to glaciation, they are restricted geographically to areas that were covered by Saalian ice. The size of these Eemian lakes is usually small, mostly not exceeding $500 \mathrm{~m}$ in diameter. The Saalian glacial depressions were filled by lacustrine deposits during the Eemian and early Weichselian, and became subsequently covered by aeolian and alluvial sediments deposited beyond the Weichselian ice sheet. The erosional nature of the ice caused removal of a number of Eemian deposits within the Weichselian glaciated area. It is therefore not surprising that the five lacustrine sites with archaeological remains occur in the area that was covered by the Saalian ice but was beyond the Weichselian maximum ice extent. The late Saalian glacial depressions filled with Eemian lacustrine sediments are found in great numbers throughout this belt, as has been shown by various drillings in Niedersachsen (e.g., Selle, 1962; Caspers et al., 1995) and Schleswig-Holstein (e.g., Menke \& Tynni, 1984; Stephan, 1995), while these lacustrine sedi- 


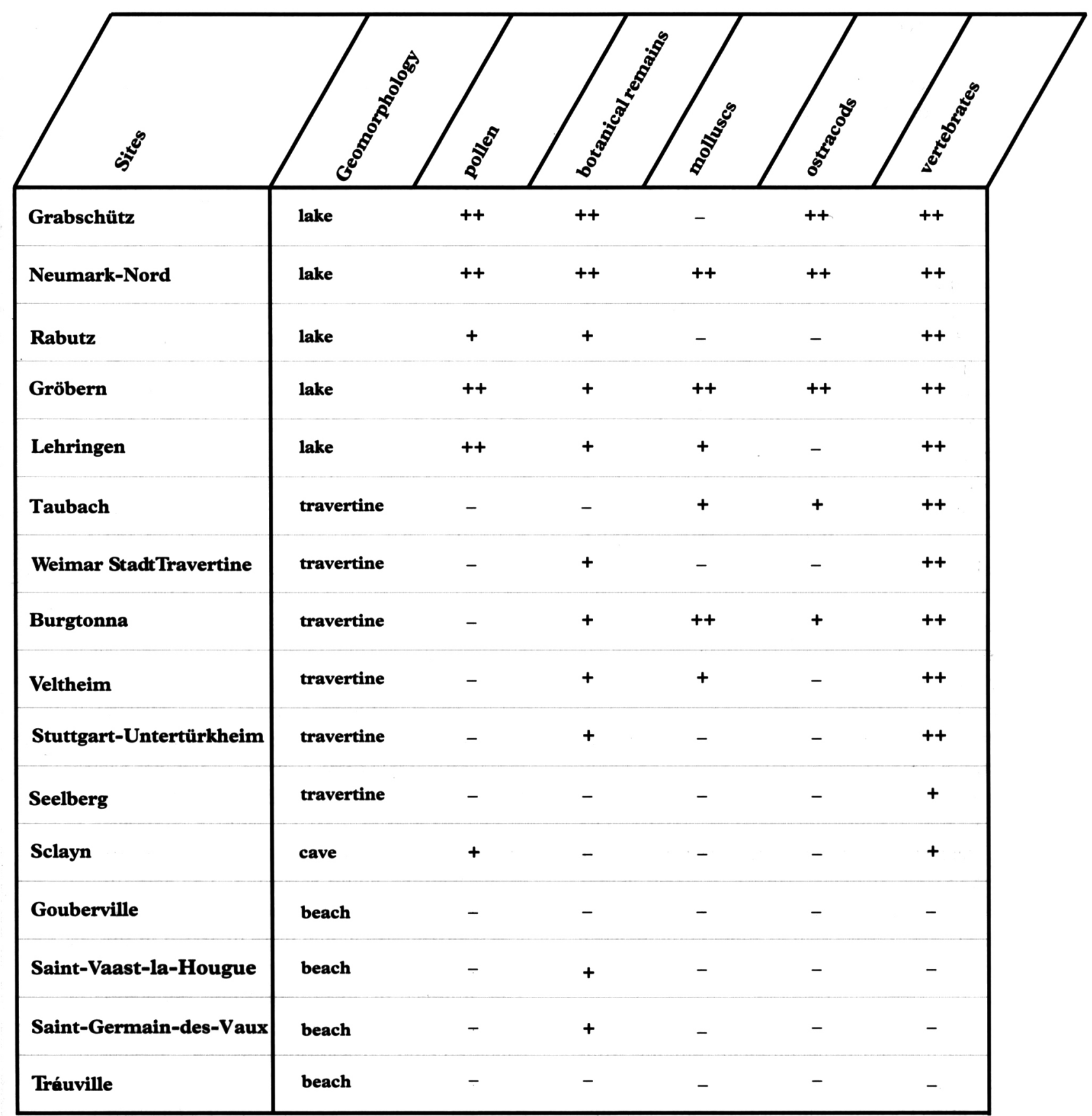

Fig. 1. The geomorphological form and the ecological contents of the archaeological sites of the Eemian. -: not present, +: present, ++: abundant or present in more than one Eemian stratigraphic layer.

ments are less common in the Netherlands. A few of these localities have been exposed, although they have largely been quarried away (e.g., at Schönfeld: Striegler \& Striegler, 1987). Although the shore sediments have been preserved, no evidence of human activities has been found.

By contrast to these lacustrine sequences, cave sites are restricted to areas where pre-Quaternary sediments are exposed. Occupation evidence of caves is scarce for the Eemian, and is in striking contrast to the abundance of occupational traces dating from the Saalian and Weichselian. In north-western Europe, only one cave - Sclayn, in Belgium (Otte et al., 1983, 1988) - is thought to have been visited during the Eemian. The Eemian levels (VIII-XI) at this site are poor in artefacts compared to the Weichselian sequence in the cave. Sediment build-up in caves depends to a high degree on thaw/freeze cycles that loosen the sediments from the ceiling. During interglacials, sedimentation rates are low and hence occupational traces and associated floral and faunal remains have little chance of being preserved. In contrast, many speleothems - with a high preservation potential for bones and artefacts - were formed dur- 
ing the Eemian. Evidence for occupation of caves during the Eemian is very rare, not only in the NorthWestern part of Europe, but also in Czechia (Svoboda, 1999) and Southern France (Jaubert, unpublished), although speleothems dating from the Eemian are found in many caves. Artefacts are numerous in early Weichselian and Saalian cave sediments but the Eemian sediments are without human traces. This may point to a decline in occupation of caves by Neanderthals during the last interglacial.

Travertine was deposited during moist and often warm periods and is found in areas where limestone is exposed in the valley slopes (Pentecost, 1995). Groundwater seepage and carbonate precipitation resulted in the travertine formation. At six places, archaeological traces were recovered from travertines of Eemian age. They are located in travertine-rich valleys such as the Neckar valley (Stuttgart-Untertürkheim, Seelberg), the Ilm valley (Weimar Stadt Travertine, Taubach) and the Tonna valley (Burgtonna), all in Germany. Travertines are also found in the Somme Valley in France; the archaeological site at Caours, formally assigned to the last interglacial (Agache et al., 1963; Bourdier, 1969), was disputed by Tuffreau et al. (1981) as being of Eemian age. This site has yielded a relative last-interglacial age based on amino-acid analysis (Bates, 1993). The sedimentation rates of travertines are very high but sedimentation is not continuous (Steiner, 1970). The German sites of Stuttgart-Untertürkheim (Adam \& Berckhemer, 1983; Wenzel, 1996), Weimar Stadt Travertine (Toepfer, 1970; Steiner, 1984) and Taubach (Schäfer, 1981) were visited repeatedly by early humans, and these sites have yielded large quantities of artefacts.

On the coast of Cotentin (in Normandy, France), four sites have yielded archaeological remains from what are thought to be Eemian beach deposits (Fosse, 1982; Fosse et al., 1986; Lautridou, 1988). The age estimates of the deposits are based on the absolute altitude of the beach, although the beach deposits of MIS 5e and MIS 7 appear to be at almost the same altitude on the island of Jersey (Keen, 1995): a situation that could be similar on Cotentin. Only the site of Saint-Germain-des-Vaux/ Port-Racine has an absolute thermoluminescence (TL) date of $106 \pm 10 \mathrm{ka}$ for the humus-rich soil that was formed in the slope deposits overlying the beach deposits (Révillion ,1994). The Saint-Germain-des-Vaux, Gouberville and Saint-Vaast-la-Hougue sites are very rich in artefacts and have yielded several concentrations of find material.

\section{Accessibility}

The residual settlement pattern is also determined by the distribution of Eemian sediments across Northern Europe and by the selection of sites that contain palaeontological evidence. The chance of finding archaeological remains in cores is very small and until now artefacts were found only in exposures. The majority of the Eemian sediments are exposed by anthropogenic activities. Within the area that was covered by the Saalian ice, three large opencast browncoal mining areas are present. Numerous quarries occur in the German Niederlausitz, where Eemian lacustrine sediments are exposed, among others at Schönfeld (Striegler \& Striegler, 1987, 1991), Kittlitz (Erd, 1973) and Klinge (Lippstreu et al., 1994; Striegler, 1995), and where fluviatile sediments occur at Nochten and Mühlrose (Schubert ,1979). Eemian fluviatile sediments are also located in the HelmstedtSchöningen mining area (Urban et al., 1991, 1995). The concentration of archaeological lake sites in eastern Germany is mainly a consequence of large-scale brown coal mining in the Leipzig area, which has made the small lake basins accessible for archaeological research. The absence of large-scale mining in Northern Germany and the Netherlands, and the increasing depth of the Eemian sediments towards the North Sea reduce the likelihood of exposures.

The interest of local Thuringian geologists and archaeologists in this Palaeolithic interval has resulted in excavations being recorded. The same is true for the travertines, which were already exploited in the $17^{\text {th }}$ century, and which were quarried in the last century on a larger scale, mainly for building material. The interest of local 'antiquity' collectors for the bones and artefacts that were found in the travertines triggered later excavations.

\section{Results}

The following can be concluded from the present study concerning the influence of taphonomic processes on the archaeological record of the Eemian. The majority of terrestrial Eemian deposits are of limited extent. The diameter of lacustrine deposits generally does not exceed $500 \mathrm{~m}$ and travertines are up to $2 \mathrm{~km}$ in length. All archaeological sites within lacustrine palaeoenvironments occur within the area previously covered by the Saalian ice masses. The lacustrine deposits are related to glacial structures that became waterlogged during the Eemian. The fact that archaeological sites are mainly found in the East arises from the large quarries there, which have opened the landscape and revealed the small Eemian lake in- 
fills. Most Eemian travertines have yielded artefacts, showing that these localities were visited repeatedly by early humans. The archaeological evidence for the presence of humans in caves is very limited.

It will be clear from the above that taphonomic processes strongly influence the present pattern of the geographical distribution of archaeological sites. Archaeological theories on early human behaviour are constrained by the distribution of preserved Eemian deposits across Northern Europe. Only a small area of the former surface has been preserved, the largest parts of which are overlain by marine sediments, while terrestrial deposits are of limited extent. The absence of traces of human occupation in Northern Germany, the Netherlands and Western Belgium can largely be explained by taphonomy. The sediments are to a large extent of marine origin in this area, and it is unlikely that any archaeological evidence will be found in them; terrestrial deposits have, however, been encountered in drillings. In this case, the lack of exposure of terrestrial deposits may be the key factor behind the absence of traces of Eemian occupation. In Northern France and Central Germany, there are, indeed, hardly any organic Eemian deposits and thus the bias in the archaeological record will remain.

A striking feature is the absence of traces of humans during the last interglacial in Great Britain, although many Eemian (Ipswichian) sediments are found that include both faunal and floral remains. One difference with the continent is the scarcity of Eemian lake sites, which probably reflects the limited extent of the ice sheet in Great Britain during the Saalian stage (Ehlers, 1996: 276). The Eemian deposits found are mainly organic sediments in depressions or channels within the river floodplain. Although there are potentially many opportunities to find archaeological material, no convincing evidence of the presence of humans during the Eemian has been found in Great Britain (Ashton, unpublished).

Although the sedimentary record is not continu-

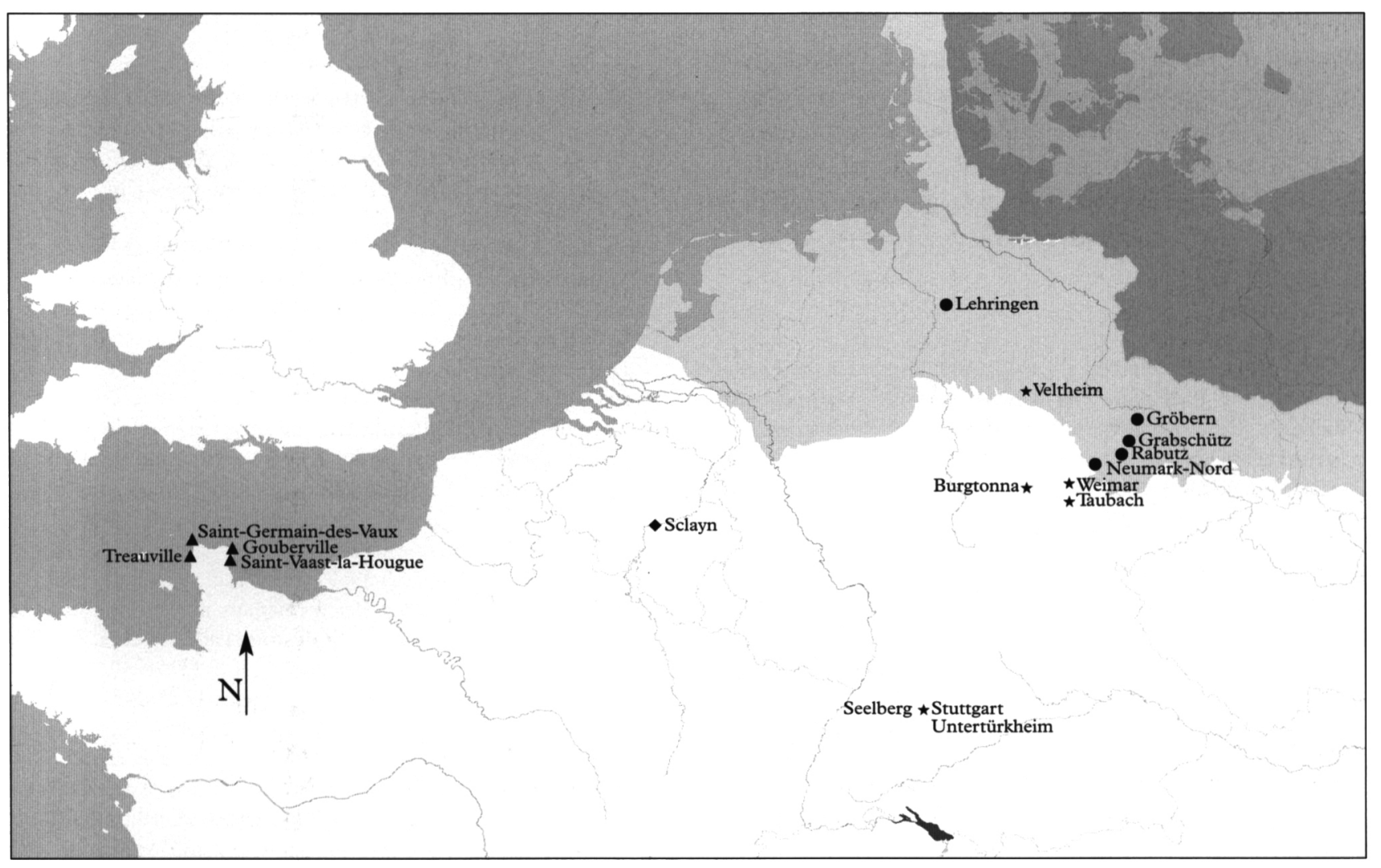

Legenda

water

Saalian ice cover

Weichselian ice cover

- archaeological remains in caves

* archaeological remains in travertine

- archaeological remains in lacustrine sediments

- archaeological remains in sub-marine sediments

Fig. 2. The archaeological sites of the Eemian in northern Europe. 
ous, a comparison is possible between - and within the preserved sedimentary settings; such comparisons leave some space for interpretation. For instance, the few remains found in caves, notwithstanding the many caves in which Eemian deposits are found, may point to the fact that humans avoided these places. A comparison between environmental characteristics within the lacustrine settings may provide an answer to the apparent absence of humans from the Niederlausitz.

The significance of the Eemian interglacial for the study of the ecological limits of early humans is in the large amount of data on archaeology, palynology, palaeontology and climatology. This evidence, potentially provides, more than in other intervals of specific climatic conditions, the foundation for the reconstruction of the environment preferred by early humans. The exceptionally fine resolution of the palynological information from the Eemian, and the interfingering of the artefact-bearing shoreline sediments with the lacustrine sediments affords an opportunity to situate the human occupation in the various pollen zones. A chronology of the occupation can thus be established, for the lake sites with a very high accuracy.

The discussion about the ecological tolerance of early humans may consequently soon be changing from differences between climatic intervals to differences between local landscapes.

\section{References}

Adam, K.D. \& Berckhemer, F., 1983. Der Urmensch und seine Umwelt im Eiszeitalter auf Untertürkheimer Markung: ein Beitrage zur Urgeschichte des Neckarlandes. Bürgerverein Untertürkheim: 66-73.

Agache, R., Boudier, F. \& Petit, R,, 1963: Le Quaternaire de la basse Somme: tentative de synthèse. Bulletin de la Societé géologique de France 7: 422-437.

Bates, M.R., 1993. Quaternary aminostratigraphy in Northwestern France. Quaternary Science Reviews 12: 793-809.

Bordes, F. \& Thibault, C., 1977. Thoughts on the initial adaptation of hominids to European glacial climates. Quaternary Research 8: 115-127.

Bosinski, G., 1992. Die ersten Menschen in Eurasien. Jahrbuch des Römisch-Germanischen Zentralmuseums Mainz 39: 131-181.

Bourdier, F., 1969. Etude comparée des depots Quaternaires des bassins de la Seine et de la Somme. Bulletin d'Informations de Géoloque du Bassin de Paris 21: 169-220.

Butzer, K.W., 1982. Archaeology as human ecology. Cambridge University Press (Cambridge): $364 \mathrm{pp}$.

Caspers, G., Jordan, H., Merkt, J., Meyer, K.-D., Müller, H. \& Streif, H., 1995. Niedersachsen. In: Benda, L. (ed.): Das Quartär Deutschlands. Gebrüder Borntraeger (Berlin): 23-50.

De Mortillet, G., 1883. Le préhistorique, antiquité de l'homme. Bibliothèque des Sciences Contemporaines (Paris): $642 \mathrm{pp}$.

Ehlers, J., 1996. Quaternary and glacial geology. John Wiley \& Sons (Chichester): $578 \mathrm{pp}$

Eissmann, L., 1994. Grundzüge de Quartärgeologie Mitteldeutschlands (Sachsen, Sachsen-Anhalt, Südbrandenburg, Thü- ringen). In: Eissmann, L. \& Litt. T. (Eds.): Das Quartär Mitteldeutschlands: ein Leitfaden und Exkursionsführer. Mit einer Übersicht über das Präquartär des Saale-Elbe-gebietes. Altenburger Naturwissenschaftliche Forschungen 7: 55-114.

Erd, K., 1973. Pollenanalytische Gliederung des Pleistozäns der Deutschen Demokratischen Republik. Zeitschrift für geologischen Wissenschaften 1: 1087-1103.

Fosse, G., 1982. Position stratigraphique et paléoenvironment du Paléolithique Ancien et Moyen de Normandie. Bulletin de l'As. sociation Française pour l'Etude du Quaternaire 2-3: 83-92.

Fosse, G., Cliquet, D. \& Vilgrain, G., 1986. Le Moustérien du Nord-Cotentin (Département de la Manche): premiers résultats de trois fouilles en cours. Bulletin de 1'Association Française por l'Etude du Quaternaire, Supplement 26: 141-155.

Gamble, C.S., 1986. The Palaeolithic settlement of Europe. Cambridge University Press (Cambridge): $471 \mathrm{pp}$.

Gamble, C.S., 1987. Man the shoveler: Alternative models for Middle Pleistocene colonization and occupation in Northern latitudes. In: Soffer, O. (ed.): The Pleistocene old world. Regional perspectives. Plenum Press (New York): 81-98.

Gamble, C.S., 1995. The earliest occupation of Europe: the environmental background. In: Roebroeks, W. \& Van Kolfschoten, Th. (eds.): The earliest occupation of Europe: proceedings of the European Science workshop at Tautavel (France), 1993. University of Leiden / European Science Foundation (Leiden): 279-295.

Guthrie, R.D., 1990. Frozen fauna of the mammoth steppe. The story of Blue Babe. The University of Chicago Press (Chicago/ London): $323 \mathrm{pp}$.

Heffley, S., 1981. The relationship between northern Athapaskan settlement patterns and resource distribution: an application of Horn's model. In: Winterhalder, B. \& Smith, E.A. (eds.): Hunter-gatherer foraging strategies. University of Chicago Press (Chicago): 126-147.

Heussner, K.-U. \& Weber, T., 1990. Das archäologische Inventar Spezielle Untersuchungen zu den Feuersteinartefakten. In: Mania, D., Thomae, D., Litt, T. \& Weber, T. (eds.): NeumarkGröbern, Beiträge zur Jagd des mittelpaläolitischen Menschen. Deutscher Verlag der Wissenschaften (Berlin): 225-236.

Keen, D.H., 1995. Raised beaches and sea-levels in the English Channel in the Middle and Late Pleistocene: problems of interpretation and implications for the isolation of the British Isles. In: Preece, R.C. (ed.): Island Britain: a Quarternary perspective. Geological Society London Special Publication 96: 63-74.

Kelly, R.L., 1983. Hunter gatherer mobility strategies. Journal of Anthropological Research 39: 277-306.

Lautridou, J.P., 1988. L'age des formations marines Pleistocènes du Cotentin comportant des industries Paléolithiques. Bulletin du Centre de Géomorphologie du C.N.R.S. 35: 79-90.

Lippstreu, L., Erd, K., Sonntag, A., Thieke, H.U., Nowel, N.W., Kühner, R., Striegler, R., Hellwig, D. \& Cepek, A.G., 1994. Die quartäre Schichtenfolge im Niederlausitzer Braunkohlentagebau Jäuschwalde (LAUBAG) und in seinem Umfeld (Exkursion A1) Altenburger Naturwissenschaftliche Forschungen 7: 151-189.

Litt, T., 1994. Paläoökologie, Paläobotanik und Stratigrafie des Jungquartärs im nordmittel europäischen Tiefland: unter besonderer Berücksichtigung des Elbe-Saale-Gebietes. J. Cramer (Berlin-Stuttgart): 185 pp.

Mania, D., Thomae, M., Litt, T. \& Weber, T., 1990. NeumarkGröbern. Beiträge zur Jagd des mittelpaläolithischen Menschen. Veröffentlichungen des Landesmuseums für Vorgeschichte in Halle 43 (Deutscher Verlag der Wissenschaften; Berlin): 319 pp.

Menke, B. \& Tynni, R., 1984. Das Eeminterglazial und das Weichselfrühglazial von Rederstall/Dithmarschen und ihre Bedeutung für die mitteleuropäische Jungpleistozän-Gliederung. Geologisches Jahrbuch A 76: 3-120. 
Noble, W. \& Davidson, I., 1996. Human evolution, language and mind: a psychological and archaeological inquiry. Cambridge University Press (Cambridge) 13:272 pp.

Obermaier, H., 1912. Der Mensch der Vorzeit. AVG (Berlin): 592 pp.

Otte, M., 1990. The northwestern European plain around 18,000 BP. In: Soffer, O. \& Gamble, C. (eds.): The world at 18,000 BP. Part I: The high latitudes. Unwin Hyman (London): 54-68.

Otte, M., Léotard, J.M., Schneider, A.M. \& Gautier, A., 1983. Fouilles aux grottes de Sclayn (Namur). Helinium 23: 112-142.

Otte, M., Evard, J.-M. \& Mathis, A., 1988. L'occupation du Paléolithique Moyen a Sclayn (Belgique). Revue Archéologique de Picardie 1-2 (Actes du Colloque 'Cultures et industries paléolithiques en milieu loessique', Amiens 9-11 Décembre 1986): 115-124.

Pentecost, A., 1995. The Quaternary travertines deposits of Europe and Asia Minor. Quaternary Science Reviews 14: 1005-1028.

Révillion, S., 1994. Position stratigraphique des industries du secteur I de Saint-Germain-Des-Vaux/Port-Racine (Manche), de Seclin (Nord) et du niveau ca de Reincourt-les-Bapaume (Pas-de-Calais). Centre d'Etudes et de Recherches Préhistoriques 5 [Les industries laminaires du Paleolithique Moyen en Europe septentrionale: l'exemple des gisement de Saint-Germain-des-Vaux/Port-Racine (Manche), de Seclin (Nord) et de Riencourt-les-Bapaume (Pas-de-Calais)]: 35-41.

Rigaud, J.-P. \& Simek, J.F., 1987. 'Arms too short to box with God': problems and prospects for Paleolithic prehistory in Dordogne, France. In: Soffer, O. (ed.): The Pleistocene old world: regional perspectives. Plenum (New York): 47-61.

Roebroeks, W., Conard, N.J. \& Van Kolfschoten, Th., 1992. Dense forests, cold steppes and the Palaeolithic settlement of Northern Europe. Current Anthropology 33: 551-586.

Schäfer, D., 1981: Taubach: zur Merkmalanalyse von Feuersteinartefakten der mittelpaläolithischen Travertinfundstell sowie zu ihrem Verhältnis zur Technologie anderer alt- und mittelpaläolithischer Fundplätze. Ethnographisches Archäologisches Zeitschrift 22: 369-396.

Schiffer, M.B., 1987. Formation processes of the archaeological record. University of New Mexico Press (Albuquerque) : $428 \mathrm{pp}$.

Schmider, B., 1990. The last Pleniglacial in the Paris Basin (22.500-17.000 BP). In: Soffer, O. \& Gamble, C. (eds.): The world at 18.000 BP. Part I: The high latitudes. Unwin Hyman (London): 41-53.

Schubert, G., 1979. Aufschlußbefunde zu einer jungpleitozänen Laufverlegung der Lausitzer Neiße (Nochtener Neiâelauf) und zur Terrassengliederung. Zeitschrift für geologische Wissenschaft (Berlin) 7: 463-477.

Selle, W., 1962. Geologische und vegetationskundliche Untersuchungen an einigen wichtigen Vorkommen des letzten Interglazials in Nordwestdeutschland. Geologisches Jahrbuch 79 : 295-351.

Steiner, W., 1970. Stratigraphie und Sedimentationsgeschwindigkeit der Travertines von Burgtonna und Ehringsdorf. Geologie 19: 931-943

Steiner, W., 1984. Der pleistozäne Travertin von Weimar. Faziesmodell einer Travertinlagerstätte. Quartärpaläontologie 5: 55210.

Stephan, H.-J., 1995. Schleswig-Holstein. In: Benda, L. (ed.): Das Quartär Deutschlands. Gebrüder Borntraeger (Berlin): 1-11.

Striegler, R., 1995. Stop 7: former clay pit ('Ältere Dominialgrube') at Klinge - Eemian deposits. In: Schirmer, W. (ed.): Exkursionen in Berlin und Umland. (INQUA Excursion guidebook: Quaternary field trips in Central Europe, volume 2. Verlag Dr. Friedrich Pfeil (München): 767-769.

Striegler, R. \& Striegler, U., 1987. Schichtenfolge, Fossilführung und Lagerungsverhältnisse im Eem-Profil von Schönfeld, Kreis Calau. Zeitschrift für geologischen Wissenschaften 13: 327-336.

Striegler, R. \& Striegler, U., 1991. Natur und Landschaft in der Niederlausitz, Sonderheft: Eem von Schönfeld I. Naturwissenschaftlicher Verein der Niederlausitz e.V. und Museum der Natur und Umwelt im Niederlausitzer Landesmuseum Cottbus, $212 \mathrm{pp}$.

Stringer, C. \& Gamble, C., 1993. In search of the Neanderthals: solving the puzzle of human origins. Thames and Hudson (London): $247 \mathrm{pp}$.

Svoboda, J., 1999. Environment and Middle Palaeolithic adaptations in eastern Central Europe. In: Roebroeks, W. \& Gamble, G. (eds.): The Middle Palaeolithic occupation of Europe: proceedings of the European Science Foundation Workshop at Arras (France) 1994. University of Leiden (Leiden): 81-92.

Thieme, H. \& Veil, S., 1985. Neue Untersuchungen zum eemzeitlichen Elefanten-Jagdplatz Lehringen, Ldkr. Verden. Die Kunde, Neue Folge 36: 11-58

Toepfer, V., 1958. Steingeräte und Palökologie der mittelpaläolithischen Fundstelle Rabutz bei Halle (Saale). Jahresschrift für Mitteldeutsche Vorgeschichte 41/42: 140-177.

Toepfer, V., 1970. Stratigraphie und Oekologie des Palaeolithikums. In: Richter, H., Haase, G., Lieberoth, I. \& Ruske, R. (eds.): Periglazial-Loess-Palaeolithikum im Jungpleistozaen der Deutschen Demokratischen Republik. VEB Hermann Haack GeographischKartographische Anhalt Gotha (Leipzig): 329-422.

Tuffreau, A., Munaut, A.-V., Puisségur, J.-J. \& Sommé, J., 1981. Les basses terrasses dans les vallées du Nord de la France et de la Picardie: stratigraphie et Paléolithique. Bulletin de la Société Préhistorique Française 78: 291-305.

Urban, B., Elsner, H., Hölzer, A., Mania, D. \& Albrecht, B., 1991. Eine Eem- und frühweichselzeitliche Abfolge im Tagebau Schöningen, Landkreis Helmstedt. Eiszeitalter und Gegenwart 41:85-99.

Urban, B., Thieme, H., Mania, D. \& Van Kolfschoten, Th., 1995. Mittel- und jungpleistozäne und holozäne Abfolgen im Tagebau Schöningen (Niedersachsen) - Archäologie, Geologie, Biostratigraphie. In: Schirmer, W. (ed.): Exkursionen in Berlin und Umland (INQUA Excursion guidebook: Quaternary field trips in Central Europe, volume 4). Verlag Dr. Friedrich Pfeil (München): 1253-1255.

Waters, M.R., 1992. Principles of geoarchaeology: a North American perspective. The University of Arizona Press (Tuscon): $398 \mathrm{pp}$.

Waters, M.R. \& Kuehn, D.D., 1996. The geoarchaeology of place: the effect of geological processes on the preservation and interpretation of the archaeological record. American Antiquity 61: 483-497.

Weber, T., 1990. Paläolithische Funde aus den Eemvorkommen von Rabutz, Grabschütz und Gröbern. Altenburger Naturwissenschaftliche Forschungen 5: 282-299.

Weber, T. \& Litt, T., 1991. Der waldelephantenfund von Gröbern, Kreis Gräfenheinichen. Jagdbefund oder Nekrophagie? Archäologisches Korrespondenzblatt 21: 17-32.

Wenban-Smith, F., 1992. Comments on Roebroeks, W., Conard, N.J. \& Kolfschoten, T.van, 1992: Dense forests, cold steppes and the Palaeolithic settlement of Northern Europe. Current Anthropology 33: 576-578.

Wenzel, S., 1996. Die Funde aus dem Travertin von Stuttgart-Untertürkheim und die Archäologie der letzten Warmzeit in Mitteleuropa. Doktor Thesis Universität Köln: 388 pp.

Whallon, R., 1989. Elements of cultural change in the Later Palaeolithic. In: Mellars, P. \& Stringer, C. (eds.): The human revolution: behavioural and biological perspectives on the origin of modern humans, vol. 1. Edinburgh University Press (Edinburgh): 433-454. 